\title{
The effectiveness of online teaching and learning tools
}

Students' perceptions of usefulness in an upper-level accounting course

\author{
Heba Abdel-Rahim
}

\begin{abstract}
This study investigates how students in a distance-learning upperlevel accounting course perceive the effectiveness of different online teaching and learning (OTL) tools that are commonly used in business courses taught online. This topic is of critical importance, especially as the COVID-19 pandemic has pushed more courses to be OTL. A midsemester anonymous survey in an Accounting course at a public US university was conducted to measure students' perceptions about different OTL course tools. Students were asked to provide their general assessment about how effective these tools were and how they believe these tools helped them learn. Analyses and discussions of the effectiveness of different tools and their link to earlier literature and how instructors can utilise the results of the OTL survey are presented.
\end{abstract}

\section{KEYWORDS}

COVID-19 pandemic, discussion boards, effectiveness, learner perspective, online teaching and learning (OTL), virtual hours

Business schools, among many other schools, have been experiencing a steep growth in online teaching and learning (OTL) course delivery over the last decade (Allen and Seaman 2017; Mishra et al. 2020). This trend is predicted to even grow further with the recent coronavirus pandemic outbreak and the uncertainty it has raised about the safety of conducting face-to-face classroom delivery in the near future. Following the coronavirus pandemic outbreak, instructors and course designers are encouraged to convert more courses to the OTL format to hedge for any possible switching to online teaching, similar to what happened in the spring of 2020. This growth has 
resulted in a need for more integration of technology and virtual tools in the teaching process and has changed the teaching practices for many instructors (Bennett and Lockyer 2004; Wiesenberg and Stacey 2008). While some traditional face-to-face classroom tools can be transferred adequately to the online environment, the need for newer tools to reach out, virtually, to students and enhance their learning skills has been emphasised (Coomey and Stephenson 2001; Goodyear 2002; Harasim et al. 1997; Martin et al. 2019). Researchers, therefore, have studied many of the pros and cons of the OTL tools used by instructors (Bawane and Spector 2009; Bigatel et al. 2012; Darabi et al. 2006; Smith 2005). While there is also a research stream that examines learners' perspectives on online teaching (Kuzma et al. 2015; Song et al. 2004; Tanner et al. 2009), these studies focus mainly on the differences in perspectives between students who attend online versus in-person courses (e.g., Kuzma et al. 2015). Therefore, there exists a need for research to investigate how OTL tools are effective from the learners' perspective. Such examination is critical as the learner is the end-user who is directly affected by these tools, and institutions and faculty alike care about creating a favourable online environment for students. Therefore, assessing students' views of the OTL tools commonly used in online classes is important.

When trying to find a definition of OTL, as reported in the literature, Daniel McFarland and Diane Hamilton note that: "the definition of "online" varies widely and we can find no generally accepted definition' (2005: 25). Some researchers, however, have defined the OTL as 'the use of the Internet to access learning materials; to interact with the content, instructor, and other learners; and to obtain support during the learning process, in order to acquire knowledge, to construct personal meaning, and to grow from the learning experience' (Ally 2004: 17). To that end, researchers examining OTL have proposed various techniques and technologies to sustain the interactive nature of learning in an online classroom. These techniques include, for example, discussion boards (Farmer 2004), instructor-made video lectures (Zhong 2017), interactive textbooks (Edgcomb et al. 2015), formation of small groups, video conferencing office hours (Dawley 2007), and more. All these tools, in addition to the currency of the curriculum, emphasise that the instructor plays the role of the facilitator. Furthermore, these tools also direct online learners to interact with each other in a virtual environment to generate discussions that simulate the learning environment of the face-toface delivery. 
Many researchers advocate for switching online classes from low-interaction to high-interaction. Hence, many online courses use the discussion boards and virtual groups to increase students' interaction and engagement with each other. While we have several research studies that highlight some best practices for OTL (e.g., Black et al. 2006; Keengwe and Kidd 2010), research on the effectiveness of different techniques and practices is still evolving. This is specifically the case for certain courses that require a focus on numerical examples and exercises to enhance the learning process, such as accounting and finance course subjects and topics.

\section{Literature review}

From the student perspective, online education is convenient as it offers learners flexible location and time (Petrides 2002; Poole 2000; Schrum 2000). For many business schools, switching to online and hybrid teaching has become a necessity to increase the convenience for many students who work part-time while pursuing their higher education and expand their educational opportunities (Hill 2002; Hofmann 2002; Rourke 2001; Trammell and Laforge 2017). Therefore, researchers have started examining the effectiveness of different OTL tools and components. The examination of effectiveness in prior research has been conducted by analysing student ratings (e.g., Arbuckle and Williams 2003), course and instructors' characteristics and the magnitude of social interactions (e.g., Gorsky and Blau 2009).

Although earlier research suggests that the flexibility afforded by OTL courses is the main attraction for many learners, learners still expect them to be of equivalent or comparable quality to face-to-face courses, to be meaningful in their contents and to allow for communication with instructors (Tricker et al. 2001). Researchers document that student satisfaction in OTL courses is significantly affected by the extent of interactions with the instructor (Ausburn 2004; Valenta et al. 2001). This critical factor is presented by earlier research as the 'immediacy behaviours' of instructors (Arbaugh 2004). While emails were the original forms of communication with the instructor, recent technological infrastructure now allows for better ways of interaction, including visual conference calls, virtual office hours, and so on. Further, virtual interactions between students can be increased by creating discussion boards and forums for virtual groups and teams to work on common cases.

In recent research, Florence Martin and colleagues (2019) conducted a survey that examined the perspectives of award-winning online faculty from 
across the United States on the effectiveness of different teaching practices. Martin et al.'s (2019) results show that faculty recommended using timely response and feedback, availability and presence, and periodic communication. Lokanath Mishra and colleagues (2020) investigated teachers' and students' perceptions of the shift to OTL at an Indian university during the pandemic. Their findings revealed that resources, instructors' readiness, student motivation and access to the internet have valuable roles in achieving integrated learning, particularly during exceptional circumstances such as COVID-19.

\section{Students' perceptions}

Earlier research focusing on examining the effectiveness, differences and similarities between the performance of students attending face-to-face classes and those attending online classes suggest the general conclusion that performance differences are not significant (Daymont and Blau 2008; McFarland and Hamilton 2005). Subsequent research has focused on attitudes and perceptions of different parties involved in online courses (e.g., students, instructors, university administrators, etc.) with regard to course design, comfortableness with online technologies, course timeline, and time constraints (Kuzma et al. 2015; Song et al. 2004; Tanner et al. 2009). The findings of these studies highlighted the importance of social interactions as a main factor to be considered for effective OTL.

\section{Perceptions regarding different online tools}

Students' perceptions of how effective the various teaching tools and course components are should be considered as important factors when designing OTL courses (O'Neill and Sai 2014). Two of the most common tools are discussion boards/forums and virtual teams and groups. A few studies have explored students' perspectives of the perceived strengths and weaknesses of these tools. For example, Lisa Petrides (2002) found that a majority of students in a web-based one-semester class reported that they were able to effectively interact with others through discussion boards. Similarly, Selma Vonderwell's (2003) interviews with twenty-two students about their perceptions show that many of the participants expressed the view that the online environment allowed them to write carefully about their ideas. Other research studies reported similar findings that virtual discussion boards and 
forums were perceived by students as fostering their responsible comments (Poole 2000). With regard to virtual teams, Petrides (2002) reported that participants felt it was easier to work in collaborative groups in an online course without rearranging schedules as they might do in a face-to-face course.

Instructors' immediacy is also an important factor that has been examined by earlier studies. Researchers generally find that the delay in responsiveness by the instructor is one of the major weaknesses perceived by students. Students expect more immediacy in responses in the online context than they typically expect in a face-to-face class discussion (Poole 2000). This factor has been specifically highlighted by earlier research in asynchronous online discussions. Specifically, previous research suggests that the 'one-onone' relationship with the instructor, even if a virtual connection, is highly appreciated by learners in an OTL environment (Vonderwell 2003). On the other hand, a main weakness in asynchronous online discussions occurs when the learners feel disconnected or isolated from their faculty as well as other learners (Woods 2002).

\section{Contribution of this study to the literature}

Prior studies have examined students' attitudes and perceptions regarding various OTL tools and techniques such as discussion boards and virtual teams on courses involving a higher degree of theory and writing (e.g., Poole's 2000 course is in Social Perspectives of Technology in Education). However, several courses in business schools involve a lower degree of theory and a higher degree of terminology and analytics (e.g., business applications and numerical problem-solving in accounting courses). Therefore, extending the examination of effectiveness and challenges of various OTL tools to more application-based courses will provide more insights to the literature as well as to instructors on how effective these tools are in fulfilling the intended learning objectives. This examination is further warranted given that earlier research suggests that students perceive online courses involving a higher degree of analytics as the most difficult to comprehend when compared to courses involving a great deal of description (e.g., history) (Kuzma et al. 2015). Therefore, this study is expected to fill in a gap in the literature in this regard with insights for accounting and business educators. 


\section{Research design}

The purpose of this exploratory study is to examine the effectiveness of various OTL tools and techniques proposed by earlier research (e.g., O'Neill and Sai 2014; Petrides 2002; Vonderwell 2003) as perceived by learners in an accounting course that involves terminology grasping as well as numerical problem-solving in business cases. This examination is specifically for an upper-level accounting course (Cost Accounting and Internal Reporting: ACCT 3320) where learning the numerical methods of measurement and costing system are among the main learning objectives. The key research questions that guided this research are as follows:

1. What are students' perspectives regarding the various OTL tools?

2. What are students' assessments of usefulness and key advantages of each of the OTL tools?

\section{Participants}

The study participants were students enrolled in an online upper-level accounting course at a mid-level Association to Advance Collegiate Schools of Business accredited business school in a public university located in the United States during the spring semester of 2020 (for the period from January till May of 2020). The course included forty-eight students. About 38 per cent of the students were females, and about 56 per cent of students were accounting majors, while the rest were either business or finance majors. In addition, the majority of students (about 84 per cent) were in their senior year (the final year of their bachelor's degree). See the summary in Table 1).

\section{Data collection}

The study adopted a mixed research methodology using both quantitative (closed-response questionnaire items) and qualitative (open-ended questions). The students in the study were contacted via a Blackboard announcement around midterm and were provided with an anonymous survey to provide their thoughts about the different online components of the course. The survey was designed to capture students' perceptions regarding the interactive course tools (e.g., discussion boards, virtual teams, virtual office hours) as well as the non-interactive tools (e.g., textbook reading, practice 
Table 1. Participants' demographics

\begin{tabular}{|l|c|c|}
\hline & $\begin{array}{c}\text { Number of learners } \\
(\mathrm{N}=48)\end{array}$ & Percent (\%) \\
\hline Gender & 30 & $62.50 \%$ \\
Male & 18 & $37.50 \%$ \\
Female & & \\
\hline Area & 27 & $56.25 \%$ \\
Accounting & 17 & $35.42 \%$ \\
Business Administration (Dual) & 2 & $4.17 \%$ \\
Finance & 1 & $2.08 \%$ \\
Undecided & 1 & $2.08 \%$ \\
Other (e.g., Mathematics) & & \\
\hline Year & 6 & $12.50 \%$ \\
Junior & 40 & $83.34 \%$ \\
Senior & 1 & $2.08 \%$ \\
Graduate & 1 & $2.08 \%$ \\
Other & & \\
\hline
\end{tabular}

Survey data are available from the author upon request.

quizzes). To ensure the credibility of the responses, the survey responses were completely anonymous and did not affect students' grades or course performance.

As presented in Figure 1, the course involved certain graded assignments that are highly dependent on the technological infrastructure of the course. These assignments included: (1) interactive textbook reading assignments (E-Book Learn Smart by Connect, a textbook published by McGraw-Hill); (2) online weekly homework assignments (completed on Connect by McGraw-Hill in which learners have three attempts with some hints and feedback provided on each attempt to improve on the previous attempt); and (3) discussion board questions which involved an open discussion of the weekly topic and required students to post their thoughts and insights on the topic and actively comment on each other's ideas. In addition, certain ungraded course tools comprised: (4) video lectures by the instructor that go over the accounting topic in detail and walk through some practice exercises to increase students' comprehension of the topic; (5) posted exercises with answers; (6) practices quizzes (also available online to students on the online Connect platform by McGraw-Hill); (7) lecture slides; (8) textbook reading; 
and (9) emailing the instructor and virtual office hours. Virtual office hours to answer learners' questions or discuss any issues they face involved oneon-one meetings between the instructor and learner either at a set time every week or by online appointment via the Blackboard video conferencing feature. The course also involved two mid-semester graded assignments including: (10) online proctored midterm exam (where learners open their webcam on their computers while sitting for the exam and are required to show their student identification card and workstation before the exam starts for them); and (11) a group assignment which involve working in groups of three online to complete a practice-oriented case based on a real-world scenario from the Institute of Management Accountants Teaching Cases.

\section{Weekly Graded Assignments}
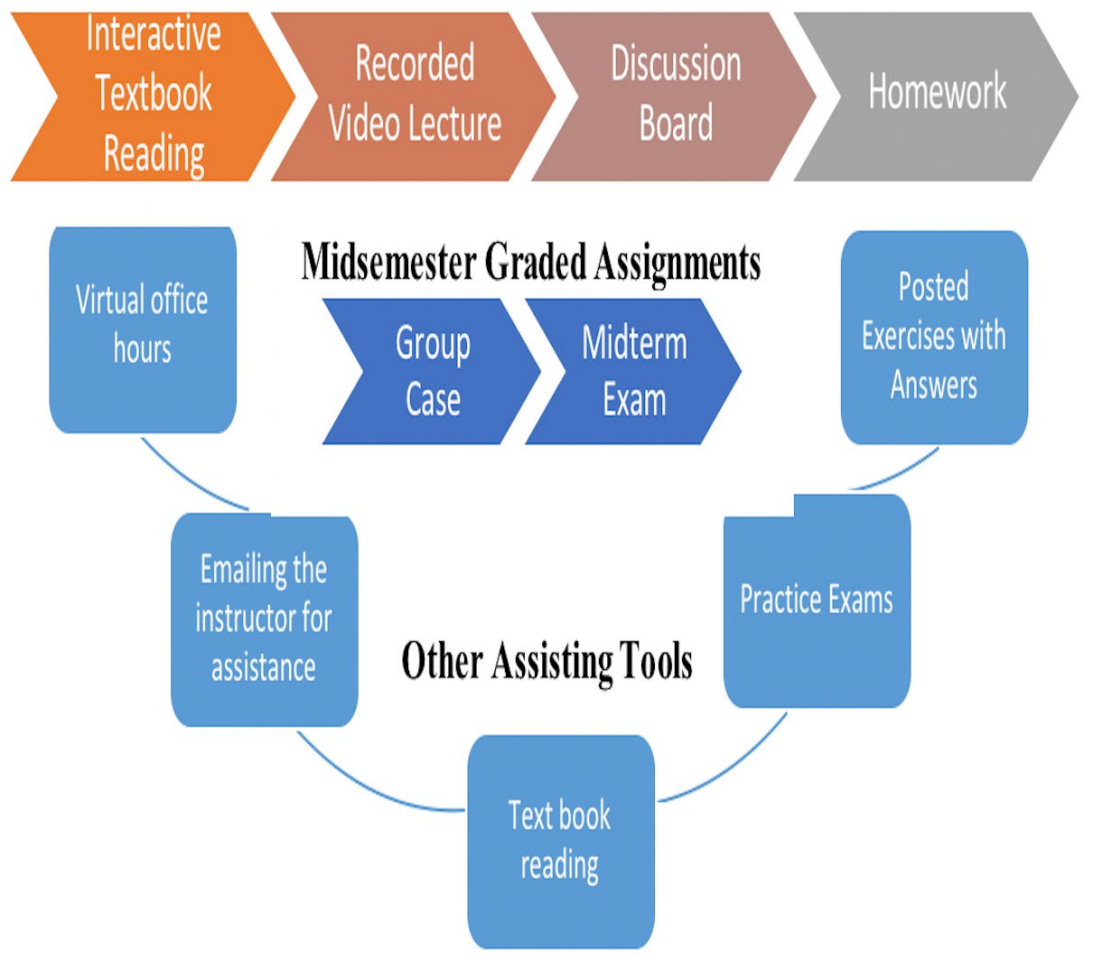

Figure 1. Online teaching components examined by the anonymous questionnaire 


\section{Results}

\section{Closed-responses questionnaire}

Students provided their responses to a question that measures the perceived usefulness of each of the course components: 'To what extent you found the following tool useful for your learning' on a scale of 1 'extremely unhelpful' and 5 'extremely helpful'. Students were also provided with an option to choose 'unknown - I never used this tool'. Results indicate certain trends in the components' overall perceived usefulness to the learners. The results in Table 2 are organised based on the classification of the OTL components as either graded or not, and as either interactive or not.

First, by considering the interactive components of the OTL accounting course, the survey results show that students perceived the non-graded interactive components: virtual office hours and emailing the professor as significantly more useful than the graded interactive components: discussion board questions and virtual group cases. On the other hand, when considering the non-interactive components, survey responses reveal that students perceived practice quizzes and posted exercises as the most useful for their learning. These findings, contrary to earlier findings in research examining a theory-driven course (Poole 2000), suggest that students perceived practices and problem-solving more useful than the interactive discussion boards. These findings may highlight the nature of upper-level accounting courses which involve a lot of accounting terminology and requires the mastery of the numerical calculations to solve business-related problems.

Figure 2 presents a rank order of all the components based on students' responses to the survey questions. Students' responses show that they perceived practice quizzes the most useful. The middle of the rank included instructor-based tools such as virtual office hours and emailing the instructor. Finally, the rank shows that students perceived discussion board assignments, group cases, and the interactive textbook reading assignment as the least helpful. Overall, these results are in line with earlier research that the instructor's immediacy remains as one of the most important factors as perceived by students. However, the results add new insights that practices and exercises play an important role in the perceived effectiveness in an OTL upper-level accounting course. 


\begin{tabular}{|c|c|c|c|c|c|c|c|c|c|c|c|c|c|c|c|}
\hline 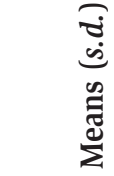 & & 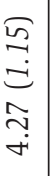 & 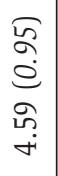 & & 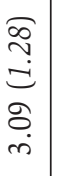 & 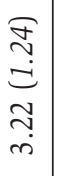 & & 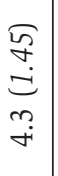 & 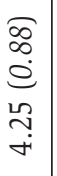 & 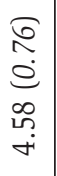 & $\begin{array}{l}\tilde{\sigma} \\
\tilde{3} \\
\hat{e} \\
\dot{+} \\
\dot{+}\end{array}$ & 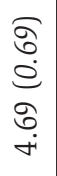 & & $\begin{array}{l}2 \\
2 \\
e \\
\infty \\
\tilde{r} \\
\dot{\sigma}\end{array}$ & 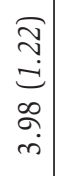 \\
\hline 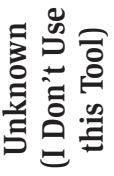 & & 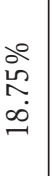 & $\begin{array}{l}\text { ○े } \\
\text { ळે } \\
\text { å }\end{array}$ & & $\begin{array}{l}\text { ○̊ } \\
8 \\
\circ \\
0\end{array}$ & $\begin{array}{l}\circ \\
8 \\
8 \\
0\end{array}$ & & $\begin{array}{l}\text { o̊ } \\
\text { Oे } \\
\text { nુ }\end{array}$ & $\begin{array}{l}\stackrel{0}{\circ} \\
\text { ठ̀ } \\
0\end{array}$ & $\begin{array}{l}\stackrel{0}{\circ} \\
\stackrel{-}{+} \\
\dot{m}\end{array}$ & $\begin{array}{l}\circ \\
\text { ठे } \\
0 \\
0\end{array}$ & $\begin{array}{l}\stackrel{0}{\circ} \\
\stackrel{8}{\circ} \\
\stackrel{0}{0}\end{array}$ & & $\begin{array}{l}00 \\
8 \\
8 \\
0\end{array}$ & $\begin{array}{l}\circ \\
\stackrel{\circ}{8} \\
\stackrel{0}{0}\end{array}$ \\
\hline 事离离 & & $\begin{array}{l}\stackrel{0}{ } \\
\stackrel{m}{\cdots} \\
\text { ñ }\end{array}$ & 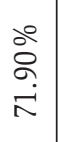 & & 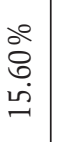 & $\begin{array}{l}\dot{0} \\
\text { రి } \\
\text { ம் }\end{array}$ & & 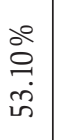 & $\begin{array}{l}\text { ᄋ̊ } \\
\text { ه } \\
0 \\
\text { ఫे }\end{array}$ & $\begin{array}{l}\stackrel{0}{N} \\
\stackrel{0}{0} \\
00\end{array}$ & $\begin{array}{l}\stackrel{0}{0} \\
\text { Oे } \\
\text { +் }\end{array}$ & $\begin{array}{l}\stackrel{0}{0} \\
\stackrel{0}{n} \\
\infty \\
\infty\end{array}$ & & 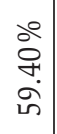 & $\begin{array}{l}\dot{0} \\
0 \\
\dot{0} \\
\dot{y}\end{array}$ \\
\hline 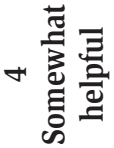 & & $\begin{array}{l}\text { o̊ } \\
\infty \\
\text { n̊. } \\
\sigma\end{array}$ & 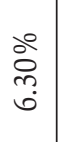 & & $\begin{array}{l}\text { ̊̊ } \\
\text { ̊े } \\
\text { ন }\end{array}$ & $\begin{array}{l}\stackrel{0}{ } \\
\text { ळे } \\
\dot{m}\end{array}$ & & $\begin{array}{l}\text { ஃ̊ } \\
8 \\
\text { ஸें }\end{array}$ & $\begin{array}{l}\text { Oे } \\
\text { Oे } \\
\text { ñ }\end{array}$ & $\begin{array}{l}0 \\
0 \\
\infty \\
\infty \\
-1\end{array}$ & $\begin{array}{l}\stackrel{0}{0} \\
\text { o } \\
\text { in }\end{array}$ & 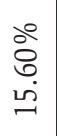 & & $\begin{array}{c}\stackrel{0}{0} \\
\varrho \\
0 \\
\stackrel{0}{\sim}\end{array}$ & $\begin{array}{l}\text { ठ̊ } \\
8 \\
\text { unं }\end{array}$ \\
\hline m莺 & & 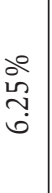 & $\begin{array}{l}\text { o̊ } \\
\text { +ి } \\
\text { aे }\end{array}$ & & 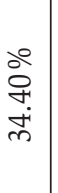 & $\begin{array}{l}\stackrel{\circ}{\circ} \\
\stackrel{\overbrace{}}{\Im} \\
\dot{\sim}\end{array}$ & & $\begin{array}{l}\text { o̊ } \\
\text { Oे } \\
\text { ă }\end{array}$ & $\begin{array}{l}\text { ᄋ̊ } \\
\text { ơ } \\
\text { å }\end{array}$ & 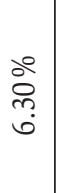 & $\begin{array}{l}\stackrel{\circ}{\circ} \\
\text { ठ } \\
0\end{array}$ & $\begin{array}{l}\stackrel{0}{ } \\
\stackrel{1}{1} \\
\dot{n}\end{array}$ & & 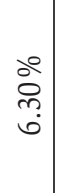 & $\begin{array}{l}0^{0} \\
\infty \\
\infty \\
\infty\end{array}$ \\
\hline 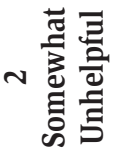 & & 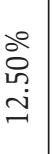 & $\begin{array}{l}\stackrel{0}{\circ} \\
\stackrel{8}{\circ} \\
\stackrel{0}{0}\end{array}$ & & 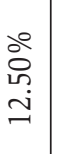 & $\begin{array}{l}\text { ○े } \\
\text { ळ } \\
\dot{\sim}\end{array}$ & & $\begin{array}{l}\stackrel{\circ}{\circ} \\
\text { ○े } \\
\dot{n}\end{array}$ & 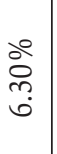 & $\begin{array}{l}\stackrel{\circ}{\circ} \\
\stackrel{-}{n}\end{array}$ & $\begin{array}{l}\stackrel{\circ}{8} \\
\stackrel{8}{\circ} \\
\stackrel{0}{0}\end{array}$ & $\begin{array}{l}\stackrel{\circ}{\circ} \\
\stackrel{!}{\text { ñ }}\end{array}$ & & $\begin{array}{l}\stackrel{0}{ } \\
\circ \\
\dot{1} \\
\dot{n}\end{array}$ & 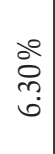 \\
\hline 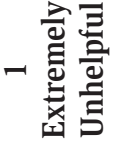 & & $\begin{array}{l}0 \\
\text { ᄋ̊ } \\
\stackrel{0}{0}\end{array}$ & 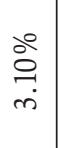 & & 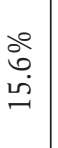 & $\begin{array}{l}\text { o̊ } \\
\text { Oे. } \\
\text { å }\end{array}$ & & 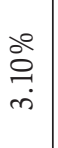 & $\begin{array}{l}\stackrel{0}{\circ} \\
\stackrel{8}{\circ} \\
\dot{0}\end{array}$ & $\begin{array}{l}\stackrel{0}{0} \\
8 \\
0 \\
0\end{array}$ & $\begin{array}{l}0 \\
0 \\
0 \\
0\end{array}$ & $\begin{array}{l}\stackrel{0}{ } \\
8 \\
\circ \\
0\end{array}$ & & $\begin{array}{l}\stackrel{0}{ } \\
\circ \\
\dot{n} \\
\dot{n}\end{array}$ & 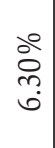 \\
\hline 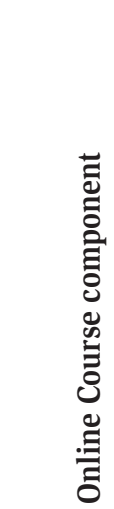 & 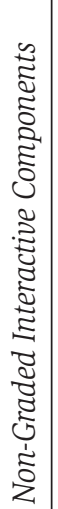 & 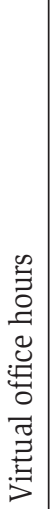 & 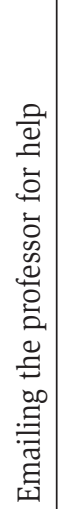 & 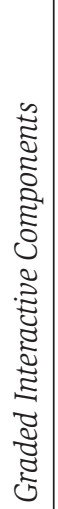 & 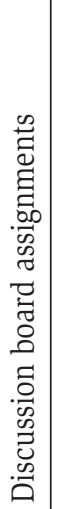 & 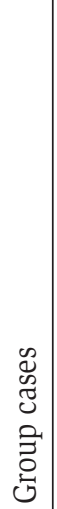 & 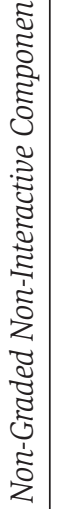 & 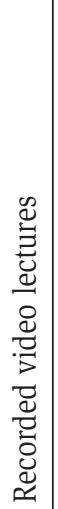 & 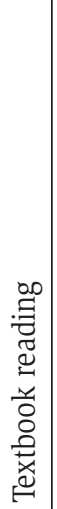 & 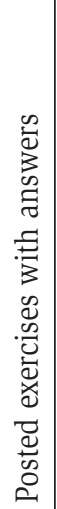 & 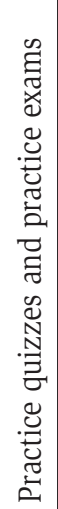 & 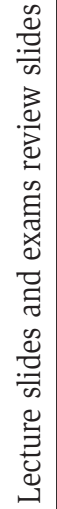 & 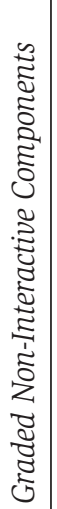 & 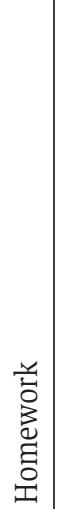 & 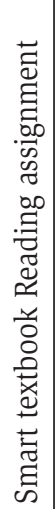 \\
\hline
\end{tabular}




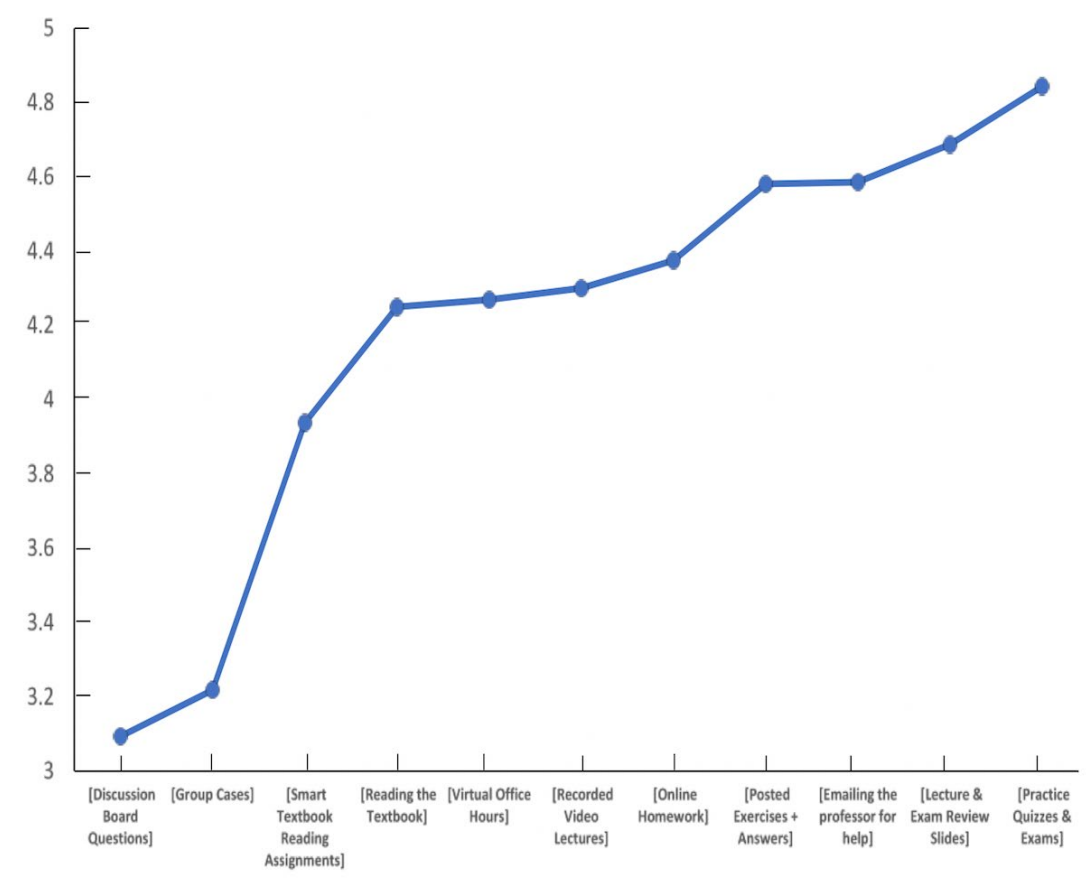

Figure 2. Rank order of the perceived usefulness of various online course components on a 5-point scale ( 1 = Extremely unhelpful; 5 = Extremely helpful)

\section{Open-ended questionnaire responses}

Participants also provided their responses to three open-ended questions that asked: 'which aspects of the course do you like the most?'; 'which aspects of the course do you like the least?'; and 'provide some suggestions for improving the course. Please feel free to add any thoughts you have'. Responses are organised in Table 3 , again, by whether the course component is graded or not, and whether it is interactive or not.

For the non-graded interactive components, students have listed mostly positive views. There was an emphasis on the clear organisation of the course platform (Blackboard) and the timeliness of the instructor responses. These views suggest, consistent with prior research, that the instructor's 'immediacy behaviour' is a critical factor for students' perceived effectiveness for the OTL course (Arbaugh 2004). With regard to graded interactive components, students provided some of their thoughts reflecting on their negative responses for the discussion boards and group cases. Specifically, 


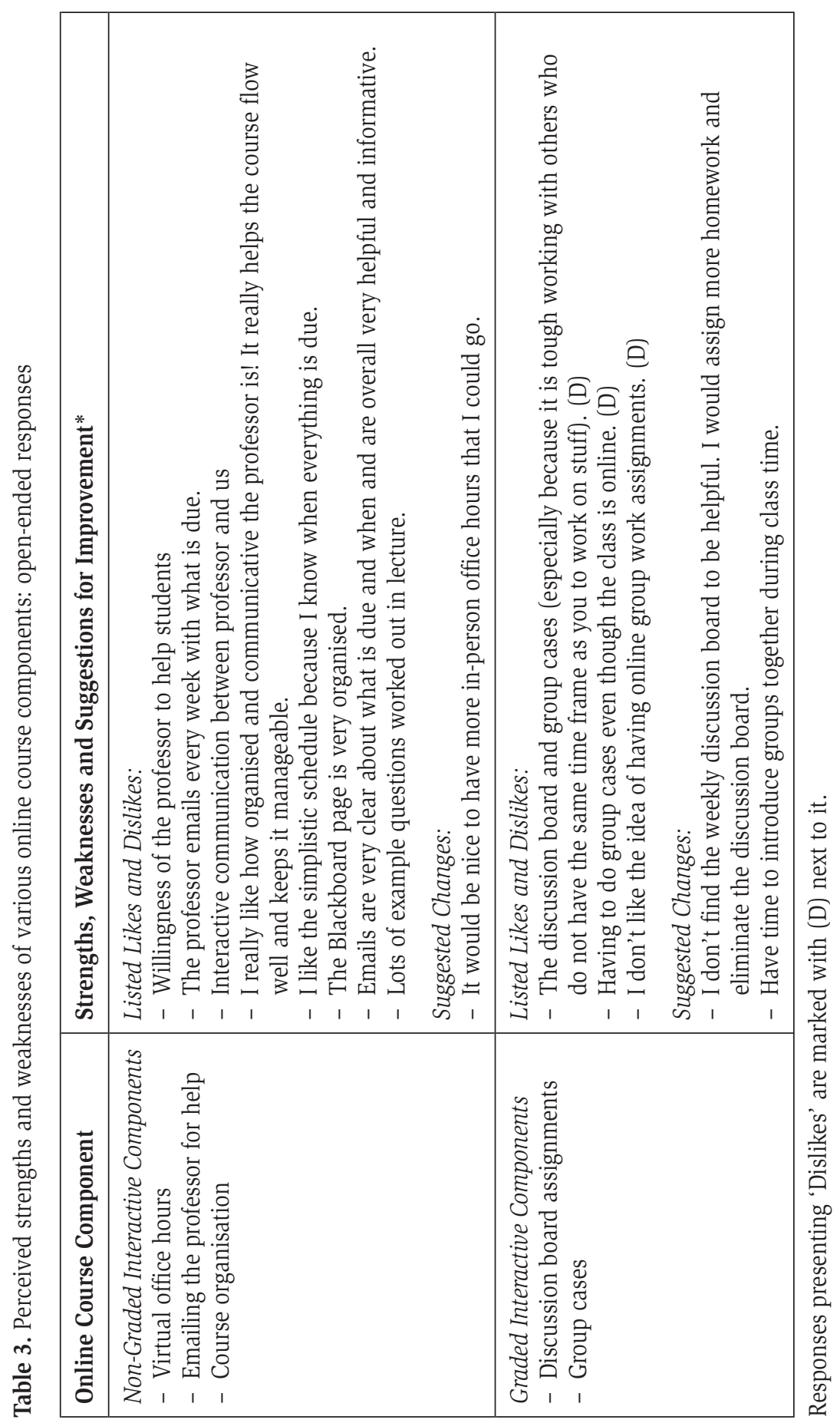




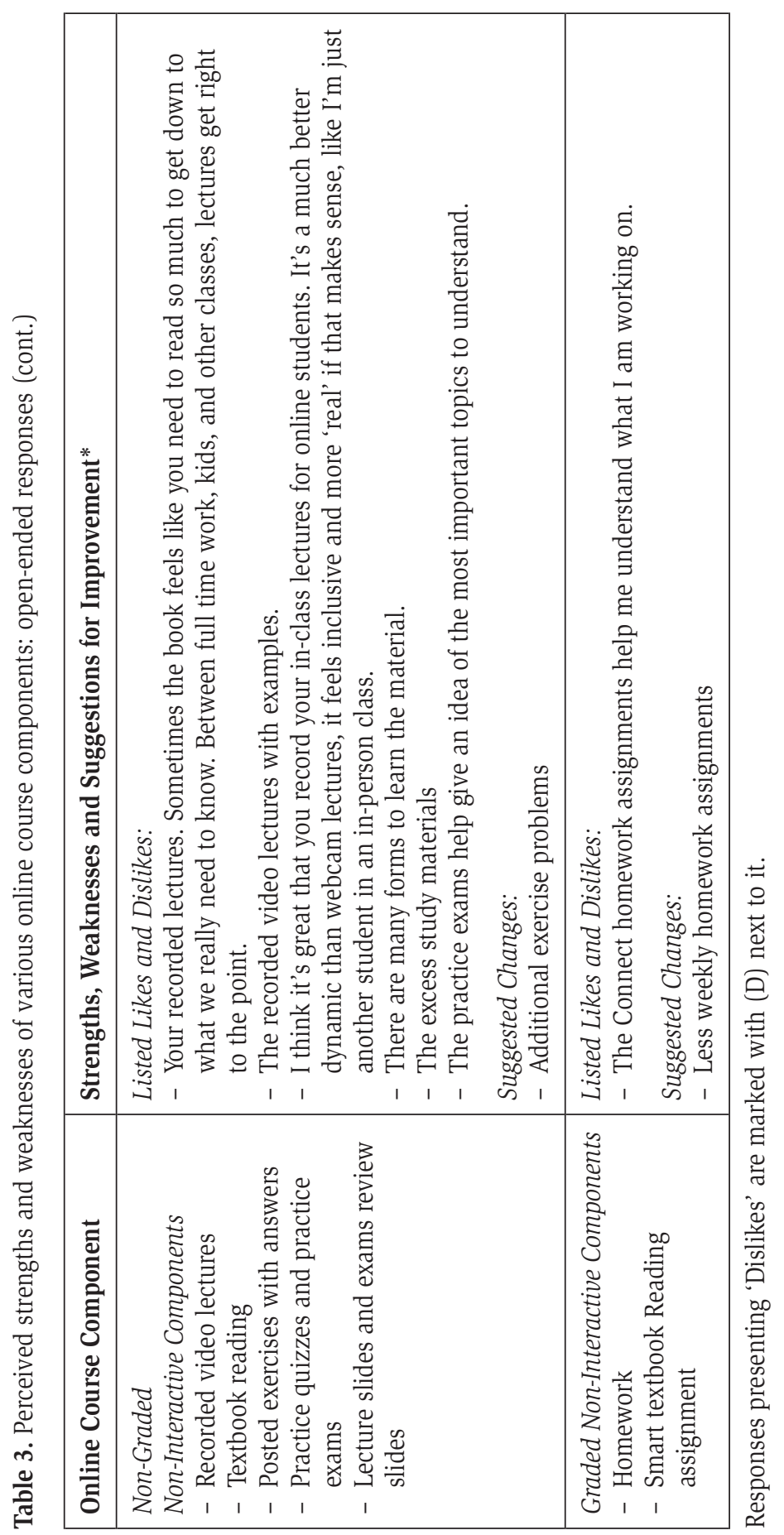


some students argued that differences in time frames across students make virtual teamwork on cases more challenging. Other students suggested that discussion board assignments were less helpful in comparison to homework assignments. This might reflect the specific nature of the cost accounting course which covers more numerical-driven problem-solving of business cases.

Finally, with regard to the non-graded non-interactive components, multiple responses expressed their liking for the recorded video lectures. One student, specifically, argued that recorded video lectures get them to learn much more effectively compared to reading the textbook alone. Other students suggested that the recording of a lecture from a live class allowed them to feel more like 'in an in-person class' rather than being online. These responses are in line with earlier studies showing that students perceive instructor-made lecture recordings of higher usefulness in learning (Zhong 2017). In addition, students listed the variety of the materials, such as solved exercises and practices as some of the perceived strengths for an online course. Overall, the results of the open-ended responses support the objective findings presented in the earlier section and suggest that the nature of upper-level accounting courses increases the perceived usefulness of practice quizzes and exercises to grasp the underlying concepts.

\section{Discussion and conclusion}

The current study focused on the learners' perceptions of the usefulness of different course tools and components in an online upper-level accounting course. Using an anonymous survey, respondents provided their insights and perspectives about which course components they identified as effective. Generally, the results of the current study agree to some extent with those presented in prior research. Specifically, some non-graded interactive course components, such as the instructor's immediacy in the form of availability via office hours and emails, were among the primary factors identified as effective. Components that ranked as the most effective, however, include the posted exercises and practice quizzes that were made available to students weekly. This suggests that the nature of the accounting topics, which has higher density of numerical problem-solving, may push for the need to integrate more of these components into an online course.

Interestingly, some graded interactive course components, such as discussion board forms and group cases, were perceived by respondents as the 
least effective, in contrast to earlier research that showed perceived benefit for discussion boards and interactive forums involving students commenting and responding to each other (Poole 2000). Present results speak specifically to an upper-level accounting class, which involves a lot of business applications, analytics, and problem-solving using numerical methods. Some students further indicated that they prefer more homework over discussion board assignments.

Overall, there is no doubt that the trend of moving accounting courses online will continue to grow. This is especially the case given some of the recent events (COVID-19 pandemic). To that end, this study's contribution to the literature is twofold. First, the study provides insights to instructors and course designers regarding the effectiveness of different OTL tools that have been examined in prior research in mostly theory-driven courses. The results of the anonymous survey presented in this study are specific to students in a mid-size public US university in an upper-level Cost Accounting course. Second, this study provides practical implications for instructors of business courses that require higher level of analytical abilities and are practiceoriented such as accounting and finance courses. Finally, future extensions of this research can conduct more robust examination of the effectiveness of OTL tools that were highlighted in this study. For example, the extent to which the results of this research can be generalised to different accounting courses (e.g., taxation, auditing) is open to future investigation. Furthermore, examination of whether the results of this survey will hold if conducted in a different country or in a private university is open for future research.

Heba Abdel-Rahim is an Assistant Professor of Accounting at the University of Toledo, Ohio, USA. She earned her PhD degree in Accounting from Georgia State University, USA, in 2016. She holds a Master of Accountancy from the University of Florida, USA (obtained in 2009), and Bachelor of Commerce degree in Accounting from Assiut University, Egypt (obtained in 2005). She is also a Certified Management Accountant (CMA). Dr. Abdel-Rahim's educational research examines the effectiveness of online teaching tools on learning outcomes with a focus on students' perspectives.

Email: hebayousef.abdel-rahim@utoledo.edu 


\section{References}

Allen, I. E. and J. Seaman (2017), Digital Learning Compass: Distance Education Enrollment Report 2017 (Babson Park, MA: Babson Survey Research Group, e-Literate, and WCET).

Ally, M. (2004), 'Foundations of educational theory for online learning: Theory and practice of online learning', in T. Anderson (ed.), The Theory and Practice of Online Learning (Athabasca, AB: Athabasca University Press), 15-44.

Arbaugh, J. B. (2004), 'Learning to learn online: A study of perceptual changes between multiple online course experiences', The Internet and Higher Education 7, no. 3: 169-182. https://doi.org/10.1016/j.iheduc.2004.06.001.

Arbuckle, J. and B. D. Williams (2003), 'Students' perceptions of expressiveness: Age and gender effects on teacher evaluations', Sex Roles 49, nos. 9-10: 507-516. https://doi.org/ 10.1023/A:1025832707002.

Ausburn, L. J. (2004), 'Course design elements most valued by adult learners in blended online education environments: An American perspective', Educational Media International 41, no. 4: 327-337. https://doi.org/10.1080/0952398042000314820.

Bawane, J. and J. Spector (2009), 'Prioritization of online instructor roles: Implications for competency-based teacher education programs', Distance Education 30, no. 3: 383-397. https://doi.org/10.1080/01587910903236536.

Bennett, S. and L. Lockyer (2004), 'Becoming an online teacher: Adapting to a changed environment for teaching and learning in higher education' Educational Media International 41, no. 3: 231-248. https://doi.org/10.1080/09523980410001680842.

Bigatel, P. M., L. C. Ragan, S. Kennan, J. May and B. F. Redmond (2012), 'The identification of competencies for online teaching success', Journal of Asynchronous Learning Networks 16, no. 1: 59-77. https://doi.org/10.24059/olj.v16i1.215.

Black, E., K. Dawson and R. Ferdig (2006), 'Forgotten alumni: Online learners as donors', Academic Exchange Quarterly 10, no. 1: 43-47.

Coomey, M. and J. Stephenson (2001), 'Online learning: It is all about dialogue, involvement, support and control-according to the research', in John Stephenson (ed), Teaching and Learning Online (London: Routledge), 37-52.

Darabi, A. A., E. G. Sikorski and R. B. Harvey (2006), 'Validated competencies for distance teaching', Distance Education 27, no. 1: 105-122. https://doi.org/ 10.1080/01587910600654809.

Dawley, L. (2007), The Tools for Successful Online Teaching (Hershey, PA: Information Science Pub).

Daymont, T. and G. Blau (2008), 'Student performance in online and traditional sections of an undergraduate management course', Journal of Behavioral and Applied Management 9, no. 3: 275-294. https://doi.org/10.21818/001c.17151. 
Edgcomb, A., F. Vahid, R. Lysecky, A, Knoesen, R. Amirtharajah and M. L. Dorf (2015), 'Student performance improvement using interactive textbooks: A three-university cross-semester analysis', paper at American Society for Engineering Education 122nd Annual Conference \& Exposition, Seattle, Washington 14-17 June.

Farmer, J. (2004), 'Communication dynamics: Discussion boards, weblogs and the development of communities of inquiry in online learning environments', in R. Atkinson, C. McBeath, D. Jonas-Dwyer and R. Phillips (eds), Beyond the Comfort Zone: Proceedings of the 21st ASCILITE Conference, Perth, 5-8 December, 274-283, http:// www.ascilite.org.au/conferences/perth04/procs/farmer.htm.

Goodyear, P. (2002), 'Teaching online’, in N. Hativa and P. Goodyear (eds), Teacher Thinking, Beliefs and Knowledge in Higher Education (Dordrecht: Springer), 79-101.

Gorsky, P. and I. Blau (2009), 'Online teaching effectiveness: A tale of two instructors', The International Review of Research in Open and Distributed Learning 10, no. 3: 1-27. https://doi.org/10.19173/irrodl.v10i3.712.

Harasim, L., S. R. Hiltz, L. Teles and M. Turoff (1997), Learning Networks: A Field Guide to Teaching and Learning Online (Cambridge, MA: MIT Press).

Hill, J. R. (2002), 'Overcoming obstacles and creating connections: Community building in Web-based learning environments', Journal of Computing in Higher Education 14, no. 1: 67-86. https://doi.org/10.1007/BF02940951.

Hofmann, D.W. (2002), 'Internet-based distance learning in higher education', Tech Directions 62, no. 1: 28-32, https://www.learntechlib.org/p/95322/.

Keengwe, J., and T. T. Kidd (2010), 'Towards best practices in online learning and teaching in higher education', MERLOT Journal of Online Learning and Teaching 6, no. 2: 533-541.

Kuzma, A., J. Kuzma and H. Thiewes (2015), 'Business student attitudes, experience, and satisfaction with online courses', American Journal of Business Education 8, no. 2: 121-310. https://doi.org/10.19030/ajbe.v8i2.9134.

Martin, F., A. Ritzhaupt, S. Kumar and K. Budhrani (2019), 'Award-winning faculty online teaching practices: Course design, assessment and evaluation, and facilitation', The Internet and Higher Education 42: 34-43. https://doi.org/10.1016/ j.iheduc.2019.04.001.

McFarland, D. and D. Hamilton (2005), 'Factors affecting student performance and satisfaction: Online versus traditional course delivery', Journal of Computer Information Systems 46, no. 2: 25-32.

Mishra, L., T. Gupta and A. Shree (2020), 'Online teaching-learning in higher education during lockdown period of COVID-19 pandemic', International Journal of Educational Research Open 1, 100012. https://doi.org/10.1016/j.ijedro.2020.100012.

O’Neill, K. and T. Sai (2014), 'Why not? Examining college students' reasons for avoiding an online course', Higher Education 68, no. 1: 1-14. https://doi.org/10.1007/ s10734-013-9663-3. 
Petrides, L. A. (2002), 'Web-based technologies for distributed (or distance) learning: Creating learning-centered educational experiences in the higher education classroom', International Journal of Instructional Media 29, no. 1: 69-77, https:// www.learntechlib.org/p/64241/.

Poole, D. M. (2000), 'Student participation in a discussion-oriented online course: A case study', Journal of Research on Computing in Education 33, no. 2: 162-177. https:// doi.org/10.1080/08886504.2000.10782307.

Rourke, J. R. (2001), 'Online learning: Fad or fate?’, Principal Leadership 1, no. 9: 8-14.

Schrum, L.M. (2000), 'Guarding the promise of online learning', Education Digest 66, no. 4: 43-47.

Smith, T. C. (2005), 'Fifty-one competencies for online instruction', The Journal of Educators Online 2, no. 2: 1-18. https://doi.org/10.9743/JEO.2005.2.2.

Song, L., E. Singleton, J. Hill and M. Koh (2004), 'Improving online learning: Student perceptions of useful and challenging characteristics', Internet and Higher Education 7, 59-70. https://doi.org/10.1016/j.iheduc.2003.11.003.

Tanner, J., T. Noser and M. Totaro (2009), 'Business faculty and undergraduate students' perceptions of online learning: a comparative study', Journal of Informational Systems Education 20, no. 1: 29-40, https://www.learntechlib.org/p/105718/.

Trammell, B. A., and C. LaForge (2017), 'Common challenges for instructors in large online courses: Strategies to mitigate student and instructor frustration', Journal of Educators Online 14, no. 1.

Tricker, T., M. Rangecroft, P. Long and P. Gilroy (2001), 'Evaluating distance education courses: The student perception', Assessment and Evaluation in Higher Education 26, no. 2: 165-177. https://doi.org/10.1080/02602930020022002.

Valenta, A., D. Therriault, M. Dieter and R. Mrtek (2001), 'Identifying student attitudes and learning styles in distance education', Journal of Asynchronous Learning Networks 5, no. 2: 111-127. http://dx.doi.org/10.24059/olj.v5i2.1882.

Vonderwell, S. (2003), 'An examination of asynchronous communication experiences and perspectives of students in an online course: A case study', Internet and Higher Education 6: 77-90. https://doi.org/10.1016/S1096-7516(02)00164-1.

Wiesenberg, F. and E. Stacey (2008), 'Teaching philosophy: Moving from face-to-face to online classrooms', Canadian Journal of University Continuing Education 34, no. 1: 63-69. http://dx.doi.org/10.21225/D5JP4G.

Woods, R. (2002), 'How much communication is enough in online courses? Exploring the relationship between frequency of instructor-initiated personal email and learners' perceptions of and participation in online learning', International Journal of Instructional Media 29, no. 4: 377-394, https://www.learntechlib.org/p/64266/.

Zhong, L. (2017), 'Online teaching effectiveness with instructor-made video tutorials: A case of using Explain Everything ${ }^{\mathrm{TM}}$ ', Business Education Innovation Journal 9, no. 1 : 35-42. 